\title{
Holy See (Vatican City State)
}

National Cancer Institute

\section{Source}

National Cancer Institute. Holy See (Vatican City State). NCI Thesaurus. Code C17249.

An enclave of Rome (Italy). 